\section{Capillary Mats Alter the Water Content in Medium during Mist Propagation of Dendranthema}

\author{
R.L. Geneve, ${ }^{1}$ S.T. Kester, and J.W. Buxton \\ Department of Horticulture, University of Kentucky, Lexington, KY 40546
}

Additional index words. chrysanthemum, Oasis, rockwool, rooting, cuttings, media

\begin{abstract}
A capillary mat-mist system was developed to provide near constant media water contents at differing quantities of mist. Media water contents were reduced by increasing the capillary mat height above a constant water table maintained at bench level. Increased tensions from 0 to $10 \mathrm{~cm}$ above the water table reduced water content in Oasis, rockwool, and peat-perlite by $35.4 \%, 27.6 \%$, and $17.4 \%$, respectively. There was no difference in water content for each medium when the mist quantity ranged between 600 and $1800 \mathrm{~mL} \cdot \mathrm{m}^{-2} \cdot \mathrm{h}^{-1}$, except when the capillary mat was at $9 \mathrm{~cm}$ above the water table and mist volume was $300 \mathrm{~mL} \cdot \mathrm{m}^{-2} \cdot \mathrm{h}^{-1}$. Chrysanthemum cuttings rooted best when water content was highest regardless of media. Using the peat-perlite medium, water content had the greatest impact on rooting when the mist volume was low (600 $\mathbf{m L} \cdot \mathrm{m}^{-2} \cdot \mathrm{h}^{-1}$ ). Relative water content of cuttings was lowest during the first 5 days of sticking and both reduced media water content and mist quantity resulted in the lowest internal water status for the cuttings.
\end{abstract}

Cuttings initially lack roots and therefore, propagation systems focus on reducing the vapor pressure deficit between the leaf and surrounding environment. This usually entails use of intermittent mist or high humidity systems (Hartmann et al., 2002). However, water content in the propagation medium also has a direct effect on cutting water relations and can impact their ability to initiate roots (Loach, 1988). Adequate water must be available at the cutting base to help regain turgor after transpirational water loss, while not reducing aeration in the medium. Cuttings initially absorb water through the cut end of the stem in proportion to the water content of the medium (Grange and Loach, 1983). This uptake is dependant on the cut stem contact with the water film surrounding particles of the rooting medium (Loach, 1988). Rein et al. (1991) using woody stem cuttings from a number of species, showed that water uptake was greatest the first few days after insertion and in general, the best rooting occurred in media with the highest water content. Several days after sticking cuttings, water uptake slows due to occlusions or plugging of xylem elements (Ikeda and Suzaki 1986). Some water may also enter through the leaves, but this appears to be minimal (Loach, 1988). At night, cuttings gain water through the stem, but cuttings may not regain full turgor by morning without sufficient available water (Grange and Loach 1983).

Loach (1985) felt that water content was more important than air porosity of the medium for good adventitious root formation. However, there are a number of studies that point to the importance of available oxygen in

Received for publication 30 Dec. 2002. Accepted for publication 12 May 2003.

${ }^{1}$ To whom reprint requests should be sent; e-mail Rgeneve@uky.edu. the medium on root initiation and root growth (Howard, 1975; Soffer and Burger 1988). Air content in the propagation medium should be between $12 \%$ and $20 \%$ on a volume basis (Aendekerk, 1993; Gislerød, 1982; Tilt and Bilderback, 1987).

Several methods have been used to establish constant amounts of water in growing medium. These include water tables established with porous tubes (Cao and Tibbitts, 1996) or sand beds (Gislerød, 1982; Loach, 1985). The basic mechanism used to maintain different media water content is by providing a suction force from a constant water table established at different distances from the surface of the medium. As the distance between the water table and the medium increases, the water content of the medium decreases. Sand beds have been used effectively to study the impact of media water content on rooting of cuttings using a single mist interval (Gislerød, 1982; Loach, 1985). Capillary mats can also be used to establish constant water tables (Hoffman et al., 1996). The capillary mat system permits

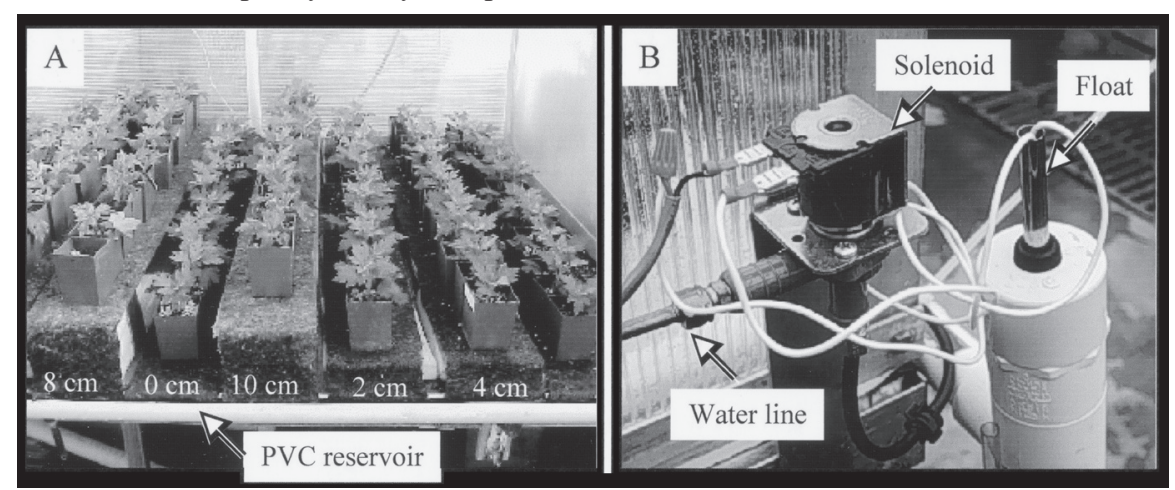

Fig. 1. Capillary mat system used to obtain different levels of water content in media during mist propagation. (A) Containers with chrysanthemum cuttings on capillary mats at several different heights above the water table (PVC reservoir). (B) Float system used to meter water to the PVC reservoir to maintain the flexibility to establish several different water tables in a small space. This allows for replicated media water treatments within a single misting unit. Therefore, the objective of the current study was to evaluate the ability of capillary mats to establish different water content levels in several propagation media exposed to differing quantities of mist. In addition, the impact of medium water content and mist quantity on root initiation and root growth was evaluated in chrysanthemum cuttings.

\section{Materials and Methods}

Three mist chambers $(1 \times 1 \times 1.2 \mathrm{~m})$ were constructed using clear polycarbonate sheets supported on an aluminum frame. One side of the chamber was open to the greenhouse. A single water line per chamber was used with four Netafim Dan fogger nozzles (Netafim, Fresno, Calif.) placed $1 \mathrm{~m}$ above the chamber base. Each line was connected to separate Richdel 24-V globe solenoids and mist intervals set using a Gemini 6 controller with Sun-Sensor (Phytotronics, Earth City, Mo.).

A level bench was constructed with $3.8-\mathrm{cm}-$ thick Styrofoam sheets. A 2.5-cm-diameter polyvinylchloride pipe was attached to the length of the bench (Fig. 1a). A $0.5-\mathrm{cm} \mathrm{sec-}$ tion was cut along the pipe's length to create a trough for capillary mat access to the water. After misting, the excess water in the medium and capillary mat was moved by capillarity into the trough and an overflow opening was created to maintain the water in the trough at bench level. Water was metered to the pipe via a small solenoid (Goyen Control, Australia) attached to a float valve (Fig. 1b). Strips $(11 \mathrm{~cm}$ $\times 1 \mathrm{~m}$ ) of Vattex $\mathrm{P}$ capillary mat (Hummert, Earth City, Mo.) were run from the water pipe up to level platforms of Styrofoam $(12 \mathrm{~cm} \times$ $1 \mathrm{~m}$ ) adjusted to the various heights above the bench top (water table).

Oasis 5015 Rootcubes (Smithers Oasis, Kent, Ohio) or $5 \times 5 \times 6 \mathrm{~cm}$ Anderson band containers (Anderson Manufacturing, Portland, Ore.) were filled with either Grodan (Hergestellt, Germany) granulated rockwool (13 g dry weight) or a 50/50 (v/v) mix of Metromix 350 and perlite ( $15.5 \mathrm{~g}$ dry weight, designated peat-perlite). Oasis blocks or media in Anderson containers were saturated 
for $24 \mathrm{~h}$ and weighed prior to being placed in mist chambers. Ten Oasis cubes or Anderson containers were placed on each capillary mat strip. Water content was calculated on a volume basis (milliliters of water per cubic centimeter of medium).

Water content of each medium was measured with capillary mat heights at $0,2,4,6$, 8 , and $10 \mathrm{~cm}$ above the water table. Water content was also measured in the morning at 8 AM before the mist was activated and at 4 PM prior to the mist being terminated for the day. To determine the relative contribution of mist to the moisture in the medium, water content in peat-perlite medium was evaluated on capillary mats held at 2 to $10 \mathrm{~cm}$ above the water table and with or without mist. In all three experiments, the mist was set for 1200 $\mathrm{mL} \cdot \mathrm{m}^{-2} \cdot \mathrm{h}^{-1}$ (12 s every $\left.8 \mathrm{~min}\right)$.

To determine the impact of mist volume and capillary mat height on media water content, the capillary mat height above the water table was held at 3,6 , or $9 \mathrm{~cm}$ and mist set at increments to supply mist water quantities between 300 to $1800 \mathrm{~mL} \cdot \mathrm{m}^{-2} \cdot \mathrm{h}^{-1}$ (ranging from $2 \mathrm{~s}$ every $16 \mathrm{~min}$ to $6 \mathrm{~s}$ every $4 \mathrm{~min}$ ). Each medium without cuttings was allowed to equilibrate for at least $60 \mathrm{~h}$ before being weighed.

For all experiments measuring media water content, there were 10 containers or Oasis blocks per treatment combination and treatments were repeated in three mist chambers.

Rooting was evaluated in 6-cm terminal cuttings of chrysanthemum [Dendranthema grandiflorum (Ramat.) Kitamura] 'Salmon Charm' stuck in each medium type on capillary mats held at $0,3,6$, and $9 \mathrm{~cm}$ above the water table. Mist quantity was $1200 \mathrm{~mL} \cdot \mathrm{m}^{-2} \cdot \mathrm{h}^{-1}$ and there were 12 cuttings per treatment combination with each treatment repeated in three chambers.

Water relations and rooting were also evaluated in chrysanthemum 'Coral Charm' cuttings. Six-centimeter terminal cuttings were stuck in equilibrated peat-perlite medium placed on capillary mats at 0,4 , and $8 \mathrm{~cm}$ above the water table. Mist quantities were 300, 600, and $1800 \mathrm{~mL} \cdot \mathrm{m}^{-2} \cdot \mathrm{h}^{-1}$. Relative water content [calculated as (fresh weight - dry weight) $\div$ (turgid weight - dry weight $) \times 100$ ] was measured after 5, 10 and $15 \mathrm{~d}$. Turgid weight was measured after floating a leaf in deionized water at $4{ }^{\circ} \mathrm{C}$ for $24 \mathrm{~h}$. Dry weight was determined after $48 \mathrm{~h}$ at $60{ }^{\circ} \mathrm{C}$. The number of roots per cutting and root dry weight were measured after $15 \mathrm{~d}$. Each treatment was replicated 3 times within each of three chambers with 12 plants per replication.

\section{Results}

Water content was reduced in each media type as the capillary mat was raised above the water table for containers misted with $1200 \mathrm{~mL} \cdot \mathrm{m}^{-2} \cdot \mathrm{h}^{-1}$ (Fig. 2). When the capillary mat was held at the same level as the water table, Oasis had the highest water content on a volume basis holding $\approx 28 \%$ and $10 \%$ more water than the peat-perlite and rockwool, respectively. Water was not removed from the Oasis medium until the mat reached $6 \mathrm{~cm}$ in height, while peat-perlite and rockwool media began to have water removed at $4 \mathrm{~cm}$. There was a $35.4 \%, 27.6 \%$, and $17.4 \%$ reduction in media water content when the capillary mat was raised from 0 and $10 \mathrm{~cm}$ for Oasis, rockwool, and peat-perlite, respectively.

In the peat-perlite medium, there was no difference in water content for containers held between 0 and $4 \mathrm{~cm}$ above the water table whether or not they were exposed to 1200 $\mathrm{mL} \cdot \mathrm{m}^{-2} \cdot \mathrm{h}^{-1}$ of mist (data not shown). However, mist reduced the amount of water withdrawn from the medium at 6,8 , and $10 \mathrm{~cm}$ by $4.1 \%$, $16.9 \%$, and $22.0 \%$, respectively, compared to the same medium not receiving mist. Similarly, there was little impact of mist volume on water content for any medium, except when the capillary mat was at $9 \mathrm{~cm}$ above the water table and mist volume was below $600 \mathrm{~mL} \cdot \mathrm{m}^{-2} \cdot \mathrm{h}^{-1}$ (Fig. 3). There was no statistical fluctuation in water content between day and night for any medium on capillary mats held between 3 and $9 \mathrm{~cm}$ above the water table. Variation between day and night water contents for peat-lite, rockwool, and Oasis ranged between $0.1 \%$ and $1.9 \%, 0.8 \%$, and $2.2 \%$, and $0.3 \%$ and $1.9 \%$, respectively.

Chrysanthemum ('Salmon Charm') cuttings produced the most roots per cutting and the largest root mass on media with the highes water content regardless of media when misted with $1200 \mathrm{~mL} \cdot \mathrm{m}^{-2} \cdot \mathrm{h}^{-1}$ (Table 1 ). The most roots were produced in the peat-perlite medium and the largest root mass was produced in the Oasis medium. For each media, root number and mass was reduced as the water content was reduced. In the peat-perlite medium, 'Coral Charm' cuttings did not show as dramatic an effect on rooting from reduced water conten in the medium compared to 'Salmon Charm', but still had reduced rooting when the mis volume was low (Table 2). At the highest mist volume $\left(1800 \mathrm{~mL} \cdot \mathrm{m}^{-2} \cdot \mathrm{h}^{-1}\right)$, rooting was unaffected by water content in the medium. Relative water content of the cuttings was affected by both mist quantity and media water content especially $5 \mathrm{~d}$ after sticking (Table 3 ).

\section{Discussion}

Capillary mats were effective in establishing near constant water contents in propagation media exposed to mist quantities typical for cutting propagation (Figs. 2 and 3). During active misting, water was withdrawn from the media proportionate to the height of the capillary mat above the water table. In contrast during the night without misting, water moved into the medium to compensate for evaporation to maintain even water content (Table 1).

With chrysanthemum cuttings, rooting was best in media with the highest water conten for each media evaluated (Table 1). Since each medium varied considerably in its bulk density, the air content would vary between media as well as at different water contents.
Table 1. Root formation in 'Salmon Charm' chrysanthemums in three media and four levels of media water content under mist $\left(1200 \mathrm{~mL} \cdot \mathrm{m}^{-2} \cdot \mathrm{h}^{-1}\right)$.

\begin{tabular}{|c|c|c|c|c|c|c|}
\hline \multirow{3}{*}{$\begin{array}{l}\text { Height above } \\
\text { the water } \\
\text { table }(\mathrm{cm})\end{array}$} & \multicolumn{6}{|c|}{ Propagation medium } \\
\hline & \multicolumn{2}{|c|}{ Peat-perlite } & \multicolumn{2}{|c|}{ Rockwool } & \multicolumn{2}{|c|}{ Oasis } \\
\hline & $\begin{array}{l}\text { Roots/ } \\
\text { cutting }\end{array}$ & $\begin{array}{l}\text { Root dry wt } \\
\text { (mg) }\end{array}$ & $\begin{array}{l}\text { Roots/ } \\
\text { cutting }\end{array}$ & $\begin{array}{l}\text { Root dry wt } \\
(\mathrm{mg})\end{array}$ & $\begin{array}{l}\text { Roots/ } \\
\text { cutting }\end{array}$ & $\begin{array}{l}\text { Root dry wt } \\
(\mathrm{mg})\end{array}$ \\
\hline 0 & $22.5 \mathrm{a}^{\mathrm{z}}$ & $28.2 \mathrm{a}$ & $13.5 \mathrm{a}$ & $23.7 \mathrm{a}$ & $12.7 \mathrm{a}$ & $41.8 \mathrm{a}$ \\
\hline 3 & $13.9 \mathrm{~b}$ & $14.5 \mathrm{~b}$ & $11.8 \mathrm{ab}$ & $13.1 \mathrm{~b}$ & $9.1 \mathrm{ab}$ & $36.1 \mathrm{a}$ \\
\hline 6 & $13.0 \mathrm{~b}$ & $12.4 \mathrm{~b}$ & $9.5 \mathrm{ab}$ & $8.7 \mathrm{~b}$ & $8.2 \mathrm{~b}$ & $38.1 \mathrm{a}$ \\
\hline 9 & $10.9 \mathrm{c}$ & $10.7 \mathrm{~b}$ & $7.6 \mathrm{~b}$ & $7.1 \mathrm{~b}$ & $4.8 \mathrm{c}$ & $23.8 \mathrm{~b}$ \\
\hline
\end{tabular}

Table 2. Root formation in 'Coral Charm' chrysanthemum cuttings in a peat-perlite medium at three quantities of mist and three levels of media water content.

\begin{tabular}{llll}
\hline Mist quantity & \multicolumn{4}{c}{ Ht above the water table $(\mathrm{cm})$} \\
\hline$\left(\mathrm{mL} \cdot \mathrm{m}^{-2} \cdot \mathrm{h}^{-1}\right)$ & 0 & 4 & 8 \\
\hline \multicolumn{4}{c}{ Roots per cutting } \\
600 & $20.6 \mathrm{a}^{\mathrm{z}} \mathrm{A}$ & $18.6 \mathrm{~b} \mathrm{~B}$ & $17.2 \mathrm{c} \mathrm{C}$ \\
900 & $20.6 \mathrm{a} \mathrm{A}$ & $19.9 \mathrm{a} \mathrm{A}$ & $19.8 \mathrm{~b} \mathrm{~A}$ \\
1800 & $22.7 \mathrm{a} \mathrm{A}$ & $21.0 \mathrm{a} \mathrm{A}$ & $22.1 \mathrm{a} \mathrm{A}$ \\
\hline
\end{tabular}

${ }^{2}$ Means followed by the same lower case letter within a column or upper case letter within a row were not different by Tukey's test $P \leq 0.05$.

Table 3. Relative water content (\%) in 'Coral Charm' chrysanthemum cuttings in a peat-perlite medium at three quantities of mist and three levels of medium moisture.

\begin{tabular}{|c|c|c|c|c|c|c|c|c|c|}
\hline \multirow{4}{*}{$\begin{array}{l}\text { Mist quantity } \\
\left(\mathrm{mL} \cdot \mathrm{m}^{-2} \cdot \mathrm{h}^{-1}\right)\end{array}$} & \multicolumn{9}{|c|}{ Days after sticking } \\
\hline & \multicolumn{3}{|c|}{$5 \mathrm{~d}$} & \multicolumn{3}{|c|}{$10 \mathrm{~d}$} & \multicolumn{3}{|c|}{$15 \mathrm{~d}$} \\
\hline & & & & $\mathrm{Ht}$ abo & he water & $\mathrm{e}(\mathrm{cm})$ & & & \\
\hline & 0 & 4 & 8 & 0 & 4 & 8 & 0 & 4 & 8 \\
\hline 600 & $50.2 \mathrm{c}^{\mathrm{z}} \mathrm{A}$ & $47.3 \mathrm{~b} \mathrm{~A}$ & $45.4 \mathrm{c} \mathrm{B}$ & $71.9 \mathrm{~b} \mathrm{~A}$ & $71.8 \mathrm{~b} \mathrm{~A}$ & $70.9 \mathrm{~b} \mathrm{~A}$ & $85.4 \mathrm{~b} \mathrm{~A}$ & $83.8 \mathrm{~b} \mathrm{~A}$ & $84.0 \mathrm{bA}$ \\
\hline 900 & $56.6 \mathrm{~b} \mathrm{~A}$ & $52.7 \mathrm{ab} A$ & $56.7 \mathrm{~b} \mathrm{~A}$ & 79.7 a A & $72.6 \mathrm{~b} \mathrm{C}$ & 76.2 a B & 90.1 a A & 87.9 a B & 94.4 a A \\
\hline 1800 & $71.6 \mathrm{a} \mathrm{A}$ & 54.7 a C & $63.1 \mathrm{a} \mathrm{B}$ & $82.1 \mathrm{a} \mathrm{A}$ & $82.1 \mathrm{a} \mathrm{A}$ & $73.2 \mathrm{~b} \mathrm{~B}$ & $94.4 \mathrm{a} \mathrm{A}$ & 87.4 a B & $84.3 \mathrm{~b} \mathrm{C}$ \\
\hline
\end{tabular}

test $P \leq 0.05$

HortScience Vol. 39(3) June 2004 


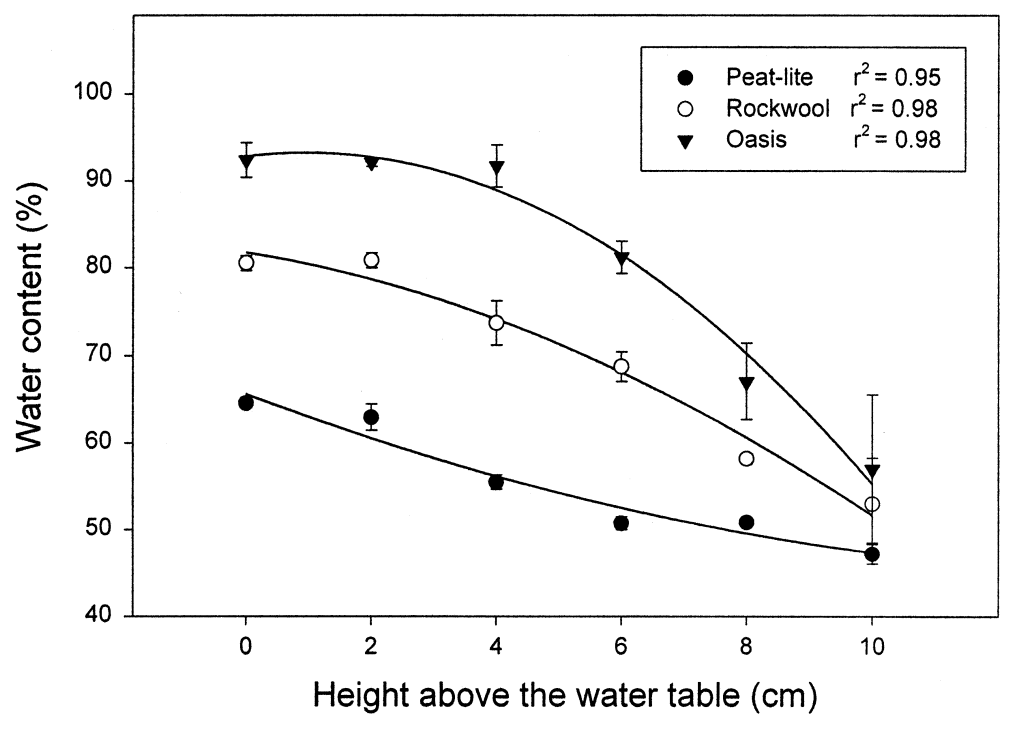

Fig. 2. Water content in three different propagation media with capillary mats held at six different heights above the water table and misted $1200 \mathrm{~mL} \cdot \mathrm{m}^{-2} \cdot \mathrm{h}^{-1}$. Each media water content fit a second order regression.

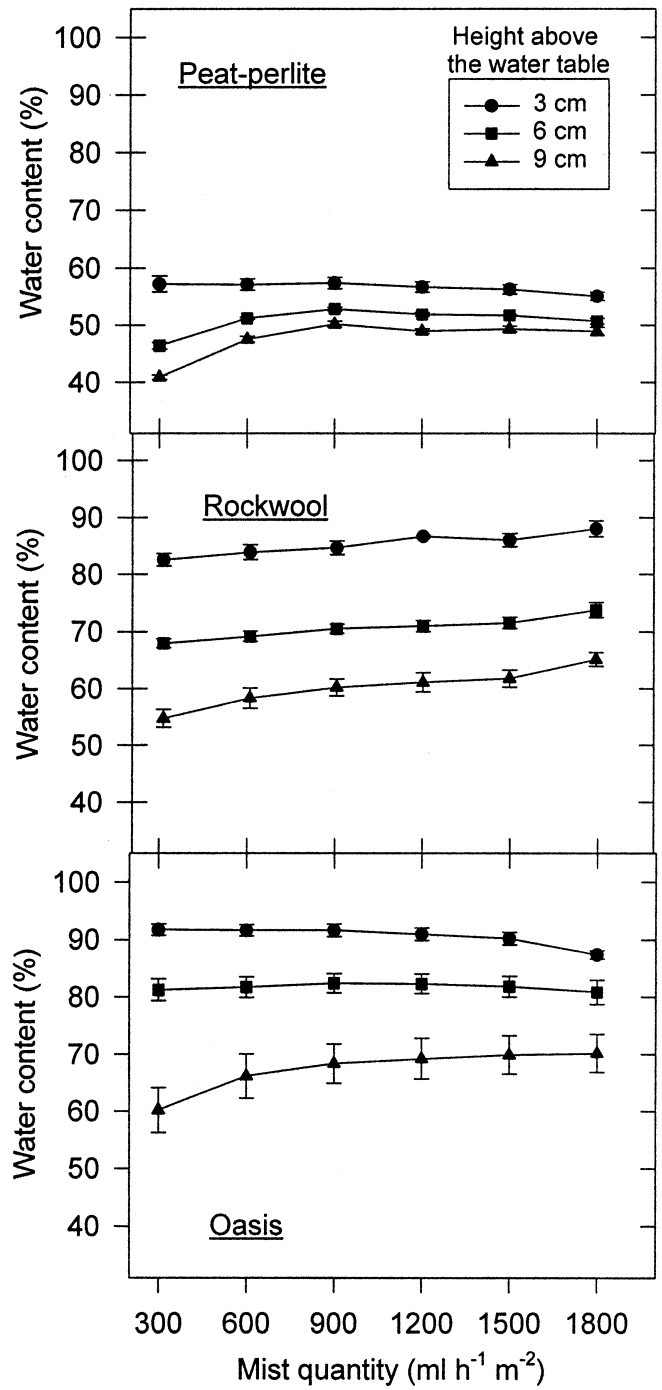

Mist quality $\left(\mathrm{mL} \cdot \mathrm{m}^{-2}\right.$ per hour $)$

Fig. 3. Water content in three different propagation media with capillary mats held at six different heights above the water table and misted with six levels of water. Main effects for mat height was significant $(P$ $\leq 0.05$ ) for each medium. Mist quantity was only significant at the $9-\mathrm{cm}$ mat height and $300 \mathrm{~mL} \cdot \mathrm{m}^{-2} \cdot \mathrm{h}^{-1}$ for each medium.
This implies that when air porosity is not limiting, water content of the medium is most important for determining rooting in chrysanthemum cuttings. The same was observed for fuchsia (Fuschsiamagelanica L.) cuttings over a range of peat-grit media and water contents between $30 \%$ and $80 \%$ (Loach, 1988). In contrast, poinsettia (Euphorbia pulcherrima Wild.) cuttings rooted better when the water content of Jiffy-7 or Grodon rockwool media was reduced by 4 or $8 \mathrm{~cm}$ of tension supplied by sand beds (Gislerød, 1982).

Previous studies using sand beds to obtain different media water contents (Gislerød, 1982; Loach, 1985) did not vary the mist quantity. The current study demonstrated that except at low mist and media water volumes, the amount of water in the medium can be controlled by the height of the capillary mat above the water table under variable misting levels (Fig. 2). Therefore, it was possible to show that media water content was more important at low mist quantities for rooting compared to higher mist volumes (Table 2). These differences in rooting were probably due to differences in the water relations of the cuttings. Chrysanthemum cuttings had a low relative water content during the first $5 \mathrm{~d}$ after sticking that was significantly impacted by both mist quantity and media water content (Table 3).

This capillary mat-mist combination also has the practical advantage of being a closed irrigation system. Excess water from the mist was collected by the capillary mat and returned to the PVC reservoir. The floor of the greenhouse was virtually dry and free from the growth of algae commonly observed at the base of mist beds.

\section{Literature Cited}

Aendekerk, T.G.L. 1993. Standards of physical properties for substrates for cuttings. Acta Hort. 342:273-278.

Cao, W. and T.W. Tibbitts. 1996. Using a poroustube system to study potato responses to constant water tension in a rooting matrix. J. Amer. Soc. Hort. Sci. 121:399-403.

Gislerød, H.R. 1982. Physical conditions of propagation media and their influence on the rooting of cuttings. I. Air content and oxygen diffusion at different moisture tensions. Plant Soil 69:445-456.

Gislerød, H.R. 1983. Physical conditions of propagation media and their influence on the rooting of cuttings. III. The effect of air content and temperature in different propagation media on the rooting of cuttings. Plant Soil 75:1-14

Gislerød, H.R, R. Baas, M. Warmenhoven, D. van den Berg, and R.U. Roeber. 1997. Effect of aeration on rooting and growth of roses. Acta Hort. 450:113-122.

Grange, R.I. and K. Loach. 1983. Environmental factors affecting water loss from leafy cuttings in different propagation systems. J. Hort. Sci. $58: 1-7$

Hoffman, M.L., J.W. Buxton, and L.A. Weston.1996. Using subirrigation to maintain soil moisture content in greenhouse experiments. Weed Sci. 44:397-401.

Howard, B.H. 1975. Improved rooting of cuttings by diffusion of oxygen through the rooting medium. J. Hort. Sci. 50:173-174.

HortSCiEnCE Vol. 39(3) June 2004 
Ikeda, T. and T. Suzaki. 1985. Influence of hydraulic conductance of xylem on water status in cuttings. Can. J. For. Res. 16:98-102

Loach, K. 1985. Rooting of cuttings in relation to the propagation medium. Proc. Intl. Plant Propagator's Soc. 35:472-485.

Loach, K. 1988. Water relations and adventitious rooting, p. 104-116. In: T.D. Davis, B.E.
Haissig and N. Sankhla (eds.). Adventitious root formation in cuttings. Dioscorides Press, Portland, Ore

Rein, W.H., R.D. Wright, and J.R. Seiler. 1991 Propagation medium moisture level influences adventitious rooting of woody stem cuttings. J. Amer. Soc. Hort. Sci. 116:632-636.

Soffer, H and D.W. Burger. 1988. Effects of dissolved oxygen concentrations in aero-hydroponics on formation and growth of adventitious roots. J. Amer. Soc. Hort. Sci. 113:218-221.

Tilt, K.M. and T.E. Bilderback. 1987. Physical properties of propagation media and their effects on rooting of three woody ornamentals. HortScience 22:245-247. 